\title{
RISK FACTORS FOR RECURRENT WHEEZING IN INFANTS
}

\author{
Wellyne Alves Lustosa ${ }^{1}$, Marta Lígia Vieira Melo ${ }^{1}$, Ubiraídys de Andrade Isidórioº \\ Milena Nunes Alves de Sousa ${ }^{3}$, Luiz Carlos de Abreu ${ }^{4}$, Vitor E. Valenti ${ }^{4,5}$, \\ Marco A. Cardoso ${ }^{5}$, Elisangela Vilar de Assis ${ }^{4}$
}

\begin{abstract}
Introduction: wheezing is one of the most common respiratory symptoms in childhood. Regardless of the cause, it is a reason to seek medical care in emergency rooms, especially if there is recurrence of episodes. Very common in childhood, recurrent wheezing has its first episodes in the first year of life. We sought to examine the risk factors for recurrent wheezing in infants in the first year of life. Methods: this is a cross-sectional quantitative study in which a standardized questionnaire of the International Study of Wheezing in Infants, translated and validated in Brazil, consisting of objective questions, applied 40 mothers were enrolled in two Family Health units. Results: the risk factors found were: smoking during pregnancy, family history of asthma, rhinitis and allergic dermatitis, the presence of at least one pet in the home at the time of birth and age at first cold less than or equal to three months of life. No significant relationships were found between males and wheezing, exclusive breastfeeding or numbers of colds in the first year of life. Conclusion: our findings are different from those reported in the literature.
\end{abstract}

Key words: risk factors; wheezing; infants; respiratory sounds.

\section{INTRODUCTION}

Wheezing is one of the most common respiratory symptoms in childhood and may result or not from any one of various lung diseases. Rcurrent wheezing is a very common condition in childhood and, in most cases, their first episodes occur in the first year of life ${ }^{1}$.

The studies of Medeiros et $\mathrm{al}^{2}$ have demonstrated several risk factors for early wheezing in children and its relationship to the subsequent development of asthma, such as prematurity, maternal smoking during pregnancy or after birth liabilities, males, respiratory infections. Relationship has also been demonstrated between wheezing and early sensitization to food and aeroallergens, reduced lung function and higher blood level of eosinophils, with subsequent persistence of these symptoms ${ }^{3,4}$.

There are few population-based studies in which the prevalence of wheezing in infants has been assessed, and are even fewer with similar methodologies to compare populations from several different localities. The first organized multicenter and multinational study with this objective was the Estudio Internacional de Sibilancias en Lactantes (EISL, International Study of wheezing in infants). With the use of validated questionnaires for communities, the author's sought to determine the prevalence of recurrent wheezing, clinical features, risk factors and the association of wheezing with respiratory infections in infants in Latin America and some countries in Europe during the first 12 months of life 5,6

Chong Neto et al. ${ }^{7}$ found that the prevalence of wheezing in infants was $45.4 \%$, with onset of seizures at 5.5 months. The number of wheezing children who had three or more seizures was $22.6 \%$, higher than in developed countries, but lower than that found in Chile among lowincome families ${ }^{8,9}$. Bianca et al. ${ }^{10}$ after using the standardized protocol of EISL observed one or

Faculdade Santa Maria, Cajazeiras, PB, Brasil.

Universidade Cruzeiro do Sul, São Paulo, SP, Brasil.

Universidade de Franca, Franca, SP, Brasil.

Faculdade de Medicina do ABC, Santo André, SP, Brasil.

5 Programa de Pós-Graduação em Fisioterapia, Faculdade de Ciências e Tecnologia, UNESP, Presidente Prudente, SP, Brasil. Corresponding author: ely.vilar@hotmail.com

Suggested citation: Lustosa WA, et al. Risk factors for recurrent wheezing in infants; Journal of Human Growth and Development 2013; 23(2): 203-208

Manuscript submitted Dec 16 2012, accepted for publication May 102012. 
more episodes of wheezing in the first 12 months of life in 467 infants (46.0\%) with mean age of symptom onset of $5.0 \pm 3.0$ months.

The following gestion emerged in the light above, mentioned studies: what are the possible risk factors that trigger wheezing in infants in the first year of life?

The undertaking of this research is justified by the high incidence and prevalence of wheezing in infants worldwide, leading to consequences for mother and child, as well as because bath wheezing in asthma is indicative of a more advanced stage of a child's life, can make it a public health problem, which calls for an investigate ton of its risk factors in infants up to 12 months. Therefore, we sought to determine the risk factors for wheezing in infants in their first year of life.

\section{METHODS}

The study was conducted in three Family Health Units (USFs) in Cajazeiras, PB, Brazil. Health units were selected for as they observe a larger number of people per unit area. The visits to the units took place in the days of checking the weight of the children in the period determined by each USF.

Among all the parents/guardians only 40 agreed to participate. We included infants of both genders, aged 12 to 24 months of and excluded infants born from mothers younger than 18 years old and older than 40 and infants with neurological and/or cardiovascular disorders.

We used a standardized questionnaire of the EISL, consisting of objective questions translated from Spanish into Portuguese and validated in Brazil by Chong Neto et al. ${ }^{6}$.

The instrument consists of 39 questions on wheezing and respiratory symptoms, lifestyle habits of the mother during pregnancy, use of medications, medical diagnoses and risk factors to be answered by the parents and/or guardians of the infants. The question is related to the period in which the children were under 12 months old.
Data were presented by using descriptive and inferential statistics. We used the Statistical Package for Social Sciences (SPSS) for Windows, version 15.0. For descriptive procedures we presented gross and relative measures (frequencies and percentages), measures of central tendency (mean) and variability (standard deviation and confidence intervals minimum and maximum). The procedures of statistical inference, were performed by means of tests: Chi-Square calculation of prevalence ratios and Mann-Whitney. The chi-square that estimates association between variables, whereas the prevalence ratio compares groups that had been exposed to particular event (in this case, wheezing) with those who had not presented such exposure or that characteristic. The Mann-Whitney test compares two groups metric variables, the choice being determined by the effective guided test sample. For the interpretation of the information, we adopted a confidence interval of $95 \%$ and a significance level of $5 \%(p<0.05)$.

\section{RESULTS}

We interviewed 40 parents of children of 1224 months old, although, the information obtained were related to the first year of life. The majority of children were male (52.5\%) and Caucasians $(69.2 \%)$. The 40 children who participated in the survey were divided almost equally into two groups: wheezing (57.5\%) and non-wheezing (42.5\%).

With the purpose of to estimating the characteristics and symptoms related to wheezing, we calculated the prevalence ratio for the two groups: (1) those who reported wheezing in the past 12 months, named wheezing, and (2) those who showed no such symptom, non-wheezing. Initially, we verified the association of these groups with the gender and race of the participants. The estimated prevalence ratio was not significant, so we cold not assume that certain gender or race had a higher chance of presenting wheezing. The descriptive and inferential data are detailed in Table 1.

Table 1: Evaluation of the prevalence of wheezing due the gender and race

\begin{tabular}{|c|c|c|c|c|c|c|c|c|c|}
\hline \multirow{2}{*}{ Variables } & \multirow[t]{2}{*}{ Esp. } & \multicolumn{2}{|c|}{ Wheezing } & \multicolumn{2}{|c|}{ Non-wheezing } & \multirow{2}{*}{$\mathbf{R P}$} & \multicolumn{2}{|c|}{ IC95\% } & \multirow{2}{*}{$\mathbf{p}$} \\
\hline & & f & $\%$ & $\mathbf{f}$ & $\%$ & & Mín. & Máx. & \\
\hline \multirow{2}{*}{ Gender } & Male & 13 & 32.5 & 8 & 20.0 & \multirow{2}{*}{1.17} & \multirow{2}{*}{0.68} & \multirow{2}{*}{2.02} & \multirow{2}{*}{0.55} \\
\hline & Female & 10 & 25.0 & 9 & 22.5 & & & & \\
\hline Ethnicity & White & $\begin{array}{c}15 \\
1.17\end{array}$ & $\begin{array}{l}38.5 \\
0.68\end{array}$ & $\begin{array}{c}12 \\
2.02\end{array}$ & $\begin{array}{l}30.8 \\
0.55\end{array}$ & 0.95 & 0.53 & 1.71 & 0.87 \\
\hline
\end{tabular}

With respect to group (1), the majority had less than three episodes of wheezing bronchitis had $(39.1 \%)$, while $30.4 \%$, each, presented 3-6, or more than six episodes. It was found that the average age to present with such symptoms was 3.83 months $(S D=3.01)$, having children who presented 
them at 1 month (minimum) or 11 months (maximum). We asked them, parther, to calculate, how many times they had agreed the night due to coughing or wheezing baby, they reported: $21.7 \%$ reported that they never slept, $30.4 \%$ reported being woken up several times, $34.8 \%$ sometimes, while $13.0 \%$ reported that they often agreed with such a problem.
It was found that the majority of children (73.9\%) were brought to an emergency service because of severe chest wheezing. $65.2 \%$ of claimants reported observing dyspnea (shortness of breath) in children, while $26.1 \%$ of children have been hospitalized for bronchitis. However, it was found that only $26.1 \%$ of them were diagnosed as having asthma. Such information is given in Table 2.

Table 2: Aspects related to wheezing in children up to 12 months

\begin{tabular}{|c|c|c|c|c|}
\hline \multirow{2}{*}{ Variables } & \multicolumn{2}{|c|}{ Yes } & \multicolumn{2}{|c|}{ No } \\
\hline & $\mathbf{F}$ & $\%$ & $\mathbf{f}$ & $\%$ \\
\hline Search emergency service & 17 & 73.9 & 6 & 26.1 \\
\hline Dyspnea & 15 & 65.2 & 8 & 34.8 \\
\hline Hospitalized for bronchitis & 6 & 26.1 & 17 & 73.9 \\
\hline Diagnosed with asthma & 6 & 26.1 & 17 & 73.9 \\
\hline
\end{tabular}

Wheezing was assessed in terms of exposure to smoke in the environments of children, prior to his/her birth or not. It was found that having a smoker or resident parent as a smoker does not constitute a factor that increases the prevalence of wheezing, however, it was found that the mothers' having smoked during pregnancy doubles the chances of the baby's presenting wheezing.

A family history of asthma, rhinitis and allergic dermatitis was also considered to be associated the prevalence of wheezing. All these variables con- stituted as significant factors for the development of wheezing, suggesting twice as likely. It was found that relatives who had asthma, rhinitis or allergic dermatitis presented nearly twice the prevalence of wheezing, compared to those who did not. The inferential data are shown in Table 3.

We evaluated in groups with no wheezing, characteristics related to childbirth, immunization and contact with animals. Regarding vaccination and contact with animals, no significant associations between these variables and wheezing, so we can not affirm that provide updated vaccination or have

Table 3: Prevalence of wheezing in environments with exposure to smoke / fumes and depending on family history

\begin{tabular}{|c|c|c|c|c|c|c|c|c|c|}
\hline \multirow[t]{2}{*}{ Variables } & \multirow[t]{2}{*}{ Group } & \multicolumn{2}{|c|}{ Wheezing } & \multicolumn{2}{|c|}{ Not Wheezing } & \multirow[t]{2}{*}{$\mathbf{R P}$} & \multicolumn{2}{|c|}{ IC95\% } & \multirow[t]{2}{*}{$\mathbf{p}$} \\
\hline & & $\mathbf{f}$ & $\%$ & $\mathbf{f}$ & $\%$ & & Mín. & Máx. & \\
\hline Resident Smoker & $\begin{array}{l}\text { Yes } \\
\text { No }\end{array}$ & $\begin{array}{l}11 \\
12\end{array}$ & $\begin{array}{l}27.5 \\
30.0\end{array}$ & $\begin{array}{c}6 \\
11\end{array}$ & $\begin{array}{l}15.0 \\
27.5\end{array}$ & 1.24 & 0.73 & 2.09 & 0.52 \\
\hline Mother's smoker & $\begin{array}{l}\text { Yes } \\
\text { No }\end{array}$ & $\begin{array}{c}6 \\
17\end{array}$ & $\begin{array}{l}15.0 \\
42.5\end{array}$ & $\begin{array}{c}5 \\
12\end{array}$ & $\begin{array}{l}12.5 \\
30.0\end{array}$ & 0.93 & 0.50 & 1.73 & 0.81 \\
\hline Smoking in pregnancy & $\begin{array}{l}\text { Yes } \\
\text { No }\end{array}$ & $\begin{array}{c}5 \\
18\end{array}$ & $\begin{array}{l}12.5 \\
45.0\end{array}$ & $\begin{array}{c}0 \\
17\end{array}$ & $\begin{array}{c}0.0 \\
42.5\end{array}$ & 1.94 & 1.40 & 2.68 & $0.04 *$ \\
\hline Familiar with Asthma & $\begin{array}{l}\text { Yes } \\
\text { No }\end{array}$ & $\begin{array}{l}13 \\
10\end{array}$ & $\begin{array}{l}32.5 \\
25.0\end{array}$ & $\begin{array}{c}3 \\
14\end{array}$ & $\begin{array}{c}7.5 \\
35.0\end{array}$ & 1.95 & 1.14 & 3.30 & $0.01 *$ \\
\hline Familiar with rinithes & $\begin{array}{l}\text { Yes } \\
\text { No }\end{array}$ & $\begin{array}{c}15 \\
8\end{array}$ & $\begin{array}{l}37.5 \\
20.0\end{array}$ & $\begin{array}{c}5 \\
12\end{array}$ & $\begin{array}{l}12.5 \\
30.0\end{array}$ & 1.87 & 1.03 & 3.39 & $0.02 *$ \\
\hline Familiar with dermatitis & $\begin{array}{l}\text { Yes } \\
\text { No }\end{array}$ & $\begin{array}{c}5 \\
18\end{array}$ & $\begin{array}{l}12.5 \\
45.0\end{array}$ & $\begin{array}{c}0 \\
17\end{array}$ & $\begin{array}{c}0.0 \\
42.5\end{array}$ & 1.94 & 1.40 & 2.68 & $0.04 *$ \\
\hline
\end{tabular}

contact with animals constitute risk factors or protective to present wheezing.

Nevertheless, there was an association of wheezing in relation to mode of delivery and have had contact with animals at birth. First, as child- birth, it was found that cesarean delivery is configured as a protective factor for wheezing. That is, someone not born by cesarean section, is more likely to have wheezing. 
In relation to contact with animals at the time of birth, the effect is opposite: a risk factor. The prevalence of wheezing was almost twice as high in homes that had pets at time of birth of children.

Wheezing was assessed as the child has presented some skin allergy in the first year of life, as well as the presence of mold or moist spots in homes

Table 4: Assessment of prevalence as birth, vaccination, contact with animals and due to allergies and mold

\begin{tabular}{|c|c|c|c|c|c|c|c|c|c|}
\hline \multirow[t]{2}{*}{ Variables } & \multirow[t]{2}{*}{ Group } & \multicolumn{2}{|c|}{ Wheezing } & \multicolumn{2}{|c|}{ Not Wheezing } & \multirow[t]{2}{*}{$\mathbf{R P}$} & \multicolumn{2}{|c|}{ IC95\% } & \multirow[t]{2}{*}{$\mathbf{p}$} \\
\hline & & $\mathbf{f}$ & $\%$ & $\mathbf{f}$ & $\%$ & & Mín. & Máx. & \\
\hline Cesarean childbirth & $\begin{array}{l}\text { Yes } \\
\text { No }\end{array}$ & $\begin{array}{c}17 \\
6\end{array}$ & $\begin{array}{l}42.5 \\
15.0\end{array}$ & $\begin{array}{c}16 \\
1\end{array}$ & $\begin{array}{c}40.0 \\
2.5\end{array}$ & 0.60 & 0.38 & 0.94 & 0.09 \\
\hline Vaccines days & $\begin{array}{l}\text { Yes } \\
\text { No }\end{array}$ & $\begin{array}{c}18 \\
4\end{array}$ & $\begin{array}{l}46.2 \\
10.3\end{array}$ & $\begin{array}{c}16 \\
1\end{array}$ & $\begin{array}{c}41.0 \\
2.6\end{array}$ & 0.66 & 0.38 & 1.13 & 0.25 \\
\hline Animal at birth & $\begin{array}{l}\text { Yes } \\
\text { No }\end{array}$ & $\begin{array}{c}9 \\
14\end{array}$ & $\begin{array}{l}22.5 \\
35.0\end{array}$ & $\begin{array}{c}1 \\
16\end{array}$ & $\begin{array}{c}2.5 \\
40.0\end{array}$ & 1.92 & 1.24 & 2.97 & $0.01 *$ \\
\hline Animal currently & $\begin{array}{l}\text { Yes } \\
\text { No }\end{array}$ & $\begin{array}{c}8 \\
15\end{array}$ & $\begin{array}{l}20.0 \\
37.5\end{array}$ & $\begin{array}{c}4 \\
13\end{array}$ & $\begin{array}{l}10.0 \\
32.5\end{array}$ & 1.24 & 0.73 & 2.11 & 0.44 \\
\hline Alergy at 1 st year of life & $\begin{array}{l}\text { Yes } \\
\text { No }\end{array}$ & $\begin{array}{c}14 \\
8\end{array}$ & $\begin{array}{l}35.9 \\
20.5\end{array}$ & $\begin{array}{l}9 \\
8\end{array}$ & $\begin{array}{l}23.1 \\
20.5\end{array}$ & 1.21 & 0.67 & 2.19 & 0.50 \\
\hline Mold in the home & $\begin{array}{l}\text { Yes } \\
\text { No }\end{array}$ & $\begin{array}{c}7 \\
15\end{array}$ & $\begin{array}{l}17.9 \\
38,5\end{array}$ & $\begin{array}{c}2 \\
15\end{array}$ & $\begin{array}{c}5.1 \\
38,5\end{array}$ & 1.55 & 0.94 & 2.56 & 0.14 \\
\hline
\end{tabular}

with wheezing showed exclusive breastfeeding within the group not exceeding hissing, as the group had wheezing and number of siblings living in the home higher than the group without wheezing. It was found also that the number of colds in the first year of life was highest in the group of sibilants. However, none of these variables showed a statistically significant these children. Nonetheless, these variables did not show significant risk factors of statistical point of view to wheezing, since the prevalence ratio showed minimal intervals of less than 1, as shown in Table 4.

Finally, we evaluated the wheezing for characteristics related to breastfeeding, colds and contacts with other people. It was found that the age group

Table 5: Evaluation of breastfeeding as wheezing, colds and contacts with others

\begin{tabular}{lcccccc} 
Variables & \multicolumn{2}{c}{ Wheezing } & \multicolumn{2}{c}{ No Wheezing } & U & P \\
& M & ST & M & ST & & \\
exclusive breastfeeding & 4.86 & 3.94 & 3.65 & 2.37 & 159.00 & 0.44 \\
Colds in 1st year & 5.05 & 3.61 & 3.65 & 3.18 & 145.00 & 0.24 \\
Age that has cooled (1 ${ }^{\text {st }}$ time) & 3.14 & 2.58 & 6.35 & 3.69 & 90.50 & $0.00 *$ \\
Number of brothers & 1.23 & 1.63 & 0.88 & 1.21 & 160.50 & 0.45 \\
No of household members & 4.73 & 2.00 & 4.53 & 2.12 & 165.50 & 0.54
\end{tabular}

\section{DISCUSSION}

Wheezing is the main complaint in doctors during infancy and in most cases related to bronchial hyperresponsiveness. Asthma and bronchiolitis are the most common causes of wheezing in infants and children, respectively ${ }^{11}$. We aimed to describe the risk factors for wheezing in infants in the first year of life.

Because it hardly established recurrent wheezing in infants shows distinct indices, ranging difference between groups. Only age was significant that the infant has cooled for the first time: the average age that babies are cooled wheezing for the first time was at 3 months, whereas it was not wheezing at 6 months, suggesting, therefore, that cold is associated with early wheezing, according to data detailed in Table 5. 
culated the prevalence ratio was not significant. The reason for this gender difference is based on lower airway caliber male relative to the female gender ${ }^{13}$, this relationship, which is reversed as the child reaches adolescence.

The "sizzle", despite its decreasing incidence with increasing age of the child, it is present throughout childhood. Longitudinal studies showed that during the first years of life the 'early transient wheezing' is quite common ${ }^{14}$.

Infants who have a family history of asthma ${ }^{2,6,15}$,rhinitis ${ }^{15}$ and allergic dermatitis have the greatest chance to present episodes of wheezing in the first 12 months of life, showing that heredity is an important risk factor for wheezing and asthma later $^{2,5,6,10,12,13}$.

Genetic factors as well as environmental exposure to allergens and not specific factors contribute to the emergence of a complex network that influences atopic diseases ${ }^{16}$.

The style and living conditions of the mother during pregnancy have a relationship with the onset of wheezing in infants, such as maternal history of asthma and tobacco use during gestation ${ }^{17}$. In our study, as in the study of Chong Neto et al. ${ }^{6}$, it was found that constant exposure of infants to tobacco in household environment after birth is not associated with factors that increase the risk of wheezing. However, Lima et al. ${ }^{5}$ indicated that uterine exposure doubles the risk. Contrary to our study, there is the research of Medeiros et al. ${ }^{2}$ who found a significant relationship between passive smoking in the household environment and not in maternal smoking during pregnancy.

The presence of domestic animals at the time of birth of the child, unlike the current presence of animals, proved to be a risk factor for the onset of wheezing in infants investigated, data consistent with the findings of Chong Neto et $\mathrm{al}^{6}$.

Exclusive breastfeeding in the first months of life is considered in some studies as a protective factor for wheezing $2,4,6,11,12,18$, which was not confirmed in our study, that shows no significance re-

\section{REFERENCES}

1. Martinez FD, Wright $A L$, Taussig LM, Holberg CJ, Halonen M, Morgan WJ. Asthma and wheezing in the first six years of life. The Group Health Medical Associates. N Engl J Med. 1995; 332(3): 133-138.

2. Medeiros D, Silva AR, Rizzo JA, Sarinho E, Mallol J, Solé D. Prevalência de sibilância e fatores de risco associados em crianças no primeiro ano de vida, residentes no Município de Recife, Pernambuco, Brasil. Cad. Saúde Pública 2011; 27(8): 1551-1559.

3. Bateman ED, Frith LF, Braunstein GL. Achieving guideline based asthma control: does the patient benefit? EurRespir J. 2002; 20(3): 588-95. garding this factor. However, according to Hanson and Korotkova Telemo ${ }^{19}$ breast milk stimulates the development of the child's immune system helping in the prevention of allergic diseases.

The amount of colds in the first year of life despite higher in the group of wheezing infants showed no significant value, but the average age that had been cold the first three months for wheezing and six months for not whistling, proposing that the lower the age at first episode of flu, the greater the risk of the baby has wheezing attacks in the future. These results are opposed to studies of other researchers ${ }^{2,6}$, showing an association between wheezing and more than six colds in the first year of life.

Respiratory disorders in infants are an important issue investigated recently ${ }^{20,21}$. The development of this research enabled the achievement of the goal initially traced, allowing to identify risk factors for recurrent wheezing in infants smoking during pregnancy, family history of asthma, rhinitis and allergic dermatitis have pet at home at the time of birth and age the first cold less than or equal to three months of life. Further, it was found that the prevalence is high.

\section{CONCLUSION}

Some risk factors in our study were similar to those found in other studies, however, factors such as male gender, presence of mold / mildew in residence, age and number of colds in the first year of life showed no statistically significant as in other studies. Further studies are needed in different regions of the country so you can have the knowledge of the true prevalence of wheezing and knowledge of risk factors that influence it.

4. Schneider AP, Stein RT, Fritscher CC. O papel do aleitamento materno, da dieta e do estado nutricional no desenvolvimento de asma e atopia. J BrasPneumol. 2007;33(4):454-462.

5. Lima JAB, Fischer GB, Sarria EE, Mattiello R, Solé $D$. Prevalência e fatores de risco para sibilância no primeiro de vida. J BrasPneumol 2010; 36(5): 525-531.

6. Chong Neto HJ, Rosário NA, Grupo EISL Curitiba (Estudio Internacional de Sibilanciasen Lactantes). Fatores de risco para sibilância no primeiro ano de vida. J Pediatr 2008; 84 (6): 495-502.

7. Chong Neto HJ, Rosário NA, Solé D, Mallol J. Prevalência de sibilância recorrente em lactentes. J Pediatr. 2007; 83 (4): 357-362. 
8. Mallol J, Andrade R, Auger F, Rodriguez J, Alvarado $R$, Figueroa $L$. Wheezing during the first year of life in infants from low-income population: a descriptive study. Allergo IImmunopathol 2005; 33:257-63.

9. Guerra S, Lohman IC, Halonen M, Martinez FD, Wright AL. Reduced interferon gamma production and soluble CD14 levels in early life predict recurrent wheezing by 1 year of age. AmJ Respir Crit Care Med. 2004; 169:70-6.

10. Bianca ACCD, Wandalsen GF, Mallol J, Solé D. Prevalência e gravidade da sibilância no primeiro ano de vida. J Bras Pneumol 2010;36(4):402-409.

11. Geraldini M, Santos HLBS, Rosário NA, Araújo $L M L$, Riedi CA et al. Quando sibilância recorrente no lactente não é asma. Rev. bras. alerg. imunopatol. 2008; 31(10):42-5.

12. Bianca ACCD, Wandalsen GF, Solé D. Lactente sibilante: prevalência e fatores de risco. Rev. bras. alerg. imunopatol. 2010; 33 (2): 43-50.

13. Muiño A, Menezes AMB, Reichert FF, Duquia RP, Chatkin M. Padrões de sibilância respiratória do nascimento até o início da adolescência: coorte de Pelotas (RS) Brasil, 1993-2004. J Bras Pneumol. 2008;34(6):347-355.

14. Wright $A L$. Epidemiology of asthma and recurrent wheeze in childhood. Clin Rev Allergy Immunol. $2002 ; 22(1): 33-44$.

15. Chatkin MN, Menezes AMB. Prevalência e fatores de risco para asma em escolares de uma coorte no Sul do Brasil. J Pediatr. 2005;81(5):411-6.

16. Halken S. Prevention of allergic disease in childhood: clinical and epidemiological aspects of primary and secondary allergy prevention. Pediatr Allergy Immunol. 2004; 15 Suppl 16: 4-5, 9-32.

17. Chong Neto HJ, Rosário NA, Grupo EISL Curitiba. Fatores de proteção e risco para sibilância recorrente no primeiro ano de vida em Curitiba. Rev. bras. alerg. imunopatol. 2009; 32(5):189-93.

18. Chong Neto HJ, Rosário NA. Sibilância no lactente: epidemiologia, investigação e tratamento. J Pediatr. 2010;86(3):171-178.

19. Hanson LA, Korotkova M, Telemo E. Breastfeeding, infant formulas, and the immune system. Ann Allergy Asthma Immunol. 2003; 90(6 Suppl 3):59-63.

20. Oliveira JS, Campos TF, Borja RO, Silva ROE, Freitas DA, de Oliveira LC, de Mendonça KMPP. Analysis of the rate of perceived exertion in the assessment of maximal respiratory pressures in children and adolescents. J Hum Growth Dev 2012;22(3):314-320.

21. Amancio CT, Nascimento LFC, Amancio TT. Environmental pollutants and odds of hospitalization for asthma in children - São José dos Campos, Brazil, in the years 2004-2005. J Hum Growth Dev 2012;22(2):202-208. 